\title{
TO CONCEPTION OF TECHNICAL EDUCATION IN THEORETICAL RESEARCH AND REFLECTION
}

\author{
Miroslav JANU*, Univerzita Palackého v Olomouci, Česká republika \\ Libuše PODLAHOVÁ, Univerzita Palackého v Olomouci, Česká republika \\ Petr VITÁSEK, ZŠ Tatenice, Česká republika
}

Přijato: 12. 4. 2016 / Akceptováno: 1. 6. 2016

Typ článku: Teoretická studie

DOI: $10.5507 /$ jtie.2016.015

Abstract: The own goal contribution is to describe the educational, material and organizational situation at the elementary schools where pupils acquire the basics of manual skills and technical thinking, which is necessary for the transition to a higher grade school. The results of field research contribution summarizes the opinions of teachers to equip school workshops, provision and use of teaching aids creativity in developing tools, the most commonly techniques used for working with wood, manifesting pupils' interest in working with wood and wood-based materials. Commentary contains the expected changes in the content of general education programs, the issue split the role of teaching and teaching qualification in creating curriculum content.

Key words: Curricular documents, Framework educational program, School

\section{K POJETÍ OBSAHU TECHNICKÉHO VZDĚLÁVÁNÍ NA ZÁKLADNÍ ŠKOLE SE ZAMĚŘENÍM NA VÝUKU O DŘEVĚ}

Abstract: Př́spěvek se zaměruje na popis a výzkum vzdělávací, materiální a organizačni situace na základnich školách, kde žáci získávají základy manuálních dovedností a technického myšlení. Ve výsledcích terénního průzkumu př́spěvek shrnuje postoje učiteli $k$ vybaveni školních dílen, zajištěni a použivání učebních pomůcek, kreativitě při tvorbě pomůcek, nejčastěji použivaným technikám práce se dřevem, projevovaném zájmu žáků o práci se dřevem a materiály na bázi dřeva. Obsahuje komentár k očekávaným změnám vobsahu rámcových vzdělávacích programů, problematice děleného vyučování a úloze aprobovanosti učitelů při tvorbě obsahu učiva.

Klíčová slova: technické vzdělávání, práce se dřevem, základní škola.

*Autor pro korespondenci: miroslav.janu@upol.cz 


\section{1 Úvod}

Od zavedení rámcových a školních vzdělávacích programů uplynula již delší doba (od r. 2005), která je dostačující na to, aby se projevily jejich efekty. Komplexní analýza výsledků reformy ještě neexistuje, objevují se zatím dílči práce, které nahližejí na problematiku $\mathrm{z}$ různých úhlů pohledu, podle zaměření autorů, jejich zájmů či profesní specializace. Např́klad D. Moree zkoumá názory učitelů na změny, které reforma přinesla (Moree, D. 2013). Také jsou již zpracovány názory učitelů na odborné školství (Knecht, P., Šumavská, G. a kol, 2011), př́padně se reflektují názory a zkušenosti učitelů různých předmětů. Je to přirozené, reflexe a evaluace výchovně vzdělávací skutečnosti musí být založena na zjištěních z jednotlivých oblastí, tj. z pohledu jednotlivých předmětů či vzdělávacích oblastí. V našem př́ípadě se zaměřjeme na předmět Pracovní vyučování na ZŠ a jeho využití pro potřeby technicky orientovaných středních škol. Tématem prríspěvku je teoretická reflexe současné výuky o zpracování dřeva (a materiálů na bázi dřeva) v pracovních činnostech na základní škole z hlediska potřeb středních technických škol a na druhé straně praktická reflexe prostřednictvím orientačního průzkumu pracovního vyučování na střední odborné škole. Vede nás $\mathrm{k}$ tomu $\mathrm{i}$ to, že jednota teorie a praxe je $\mathrm{v}$ současné době akcentována $\mathrm{v}$ př́spěvcích našich i zahraničních autorů, především didaktiků oborů; např. Hüttner, A. (2015).

\section{K aktuální podobě technického vzdělávání na základní škole}

Současné názvy předmětů technického zaměření se na jednotlivých základních školách liší, např. pracovní vyučování, pracovní výchova, praktické činnosti, polytechnická výchova. Přesný název není vymezen žádným školským dokumentem. Základní úvahou, ze které vycházíme, je fakt, že se vždy jedná o technicky zaměřený obsah (realizovaný prostřednictvím pracovních činností (včetně teoretických poznatků), na který by měla navazovat technická výchova a středním stupni vzdělávání (v učebním oboru). Proto budeme používat termínu pracovní činnosti, který vyjadřuje praktický charakter obsahu výuky. Zajímají nás organizační a materiální podmínky škol, volba tematických okruhů, zájem žáků o práci s jednotlivými pomůckami a materiály, podíl učitelů na tvorbě ŠVP, ochota učitelů ke změnám, nejčastěji užívané techniky a postupy.

Systematicky pojaté technické vzdělávání není v Rámcovém vzdělávacím programu pro základní vzdělávání zcela zřetelné. Je třeba prostudovat všechny části RVP ZV a teprve po podrobnějším rozboru je patrné, že $\mathrm{k}$ rozvoji technických kompetencí žáků přispívá ve svých tématech více či méně většina vzdělávacích oborů a průřezových témat, že klíčové kompetence korespondují s většinou požadavků na nové dovednosti a že těžiště praktické výuky s vlastním, technicky zaměřeným vzdělávacím obsahem leží ve vzdělávací oblasti Člověk a svět práce. RVP pro základní vzdělávání ve své aktualizované podobě, platný od 1 . 9. 2013 definuje vzdělávací oblast Člověk a svět práce jako:

- „široké spektrum pracovních činností a technologií, které vede žáky kzískáni základnich uživatelských dovedností v rüzných oborech lidské cinnosti a přispivá k vytvárení životni a profesni orientace žáků. “

- „učivo, které se zaměruje na praktické pracovni dovednosti a návyky a doplňuje celé základni vzdèláváni o dủležitou složku nezbytnou pro uplatněni člověka v dalším životě a ve společnosti. Tím se odlišuje od ostatnich vzdèlávacích oblastí a je jejich určitou 
protiváhou. “(MŠMT: Upravený Rámcový vzdèlávaci program pro základní vzděláváni platný od 1. 9. 2013, s. 87).

Vzdělávací oblast „Člověk a svět práce“ obsahuje osm tematických okruhů. Na 2. stupni je vzdělávací obsah rozdělen do osmi tematických okruhů: Práce s technickými materiály, Design a konstruování, Pěstitelské práce a chovatelství, Provoz a údržba domácnosti, Př́prava pokrmü, Práce s laboratorni technikou, Využití digitálnich technologii a Svět práce. $\mathrm{Z}$ toho Práce s technickými materiály, Design a konstruování, Práce s laboratorni technikou, Využití digitálních technologii a částečně i Provoz a údržba domácnosti mají technicky zaměřený vzdělávací obsah. Tematické okruhy na 2 . stupni tvoří nabídku, z níž tematický okruh Svět práce je povinný.

Školy vybírají podle svých podmínek a pedagogických záměrů minimálně jeden další okruh z uvedené nabídky. Vybrané tematické okruhy je však nutné realizovat vždy v plném rozsahu - viz učivo a očekávané výstupy v RVP. (MŠMT: Upravený Rámcový vzdělávací program pro základní vzdělávání platné od 1.9. 2013, s. 87). RVP sice doporučuje zařazovat do vzdělávání žáků co největší počet tematických okruhů, ale samotná praxe je ovlivněna časovou dotací. Vycházíme-li z minimální časové dotace určené v RVP ZV k realizaci problematiky vzdělávacího oboru Člověk a svět práce a s přihlédnutím k praxi školní výuky, dostáváme se na reálných 100 až 110 vyučovacích hodin, které by měla základní škola v průběhu 2. stupně věnovat realizaci závazného vzdělávacího obsahu (jeden alternativní tematický okruh plus povinný tematický okruh Svět práce).

Učivo zahrnuje: vlastnosti materiálu, užití v praxi (dřevo, kov, plasty, kompozity), pracovní pomůcky, nářadí a nástroje pro ruční opracování, jednoduché pracovní operace a postupy, organizaci práce, důležité technologické postupy, technické náčrty a výkresy, technické informace, návody, úlohu techniky v životě člověka, zneužití techniky, techniku a životní prostředí, techniku a volný čas, tradice a řemesla. $Z$ uvedeného přehledu je zřejmé, že součástí tohoto tematického okruhu není jen praktická část výuky - zpracování technických materiálů, ale pro výuku zcela nezbytné teoretické vstupy, včetně správné terminologie, bezpečnosti a hygieny práce (Kropáč, J. 2004, Cimra, M., Očkajová, A. 2015).

\section{Použité metody}

Cílem výzkumného šetření bylo posoudit současný stav výuky předmětu Pracovní činnosti na základní škole. Bylo použito teoretických výzkumných metod, které spočívaly ve studiu publikovaných odborných statí a kurikulárních dokumentů. Získané poznatky byly podrobeny analýze a kritickému zhodnocení, s cílem uspořádat je do teoretického rámce $\mathrm{v}$ souvislosti s poznatky získanými praktickým průzkumem. K tomuto účelu jsme použili anonymní dotazníky, které jsme předkládali respondentům - učitelům vyučujících předmět pracovní činnosti na ZŠ v Pardubickém a Olomouckém kraji. V dotazníkovém šetření jsme se zaměřili na stav ŠVP, respektive volbu tematických okruhů ve vzdělávací oblasti Člověk a svět práce, časovou dotaci pro daný předmět, aprobovanost učitelü, jejich angažovanost př̀ tvorbě ŠVP, materiální vybavení školní dílny a využití pomůcek ve výuce. Pro úplnost lze dodat, že jsme se zaměřili výhradně na práci s technickými materiály - dřevem a materiály na bázi dřeva. Př́spěvek je totiž vstupní studií pro následné zkoumání jiných vyučovaných témat a jiných použivaných materiálů. Osloveni byli učitelé ze 40 škol, z toho odevzdaných 
a relevantních dotazníků, které jsme zpracovali, bylo 32. Anonymní dotazník (12 položek) obsahoval jak otázky dichotomické, tak otázky s výběrem většího počtu odpovědí.

\section{Výsledky dotazníkového šetření a jejich diskuse}

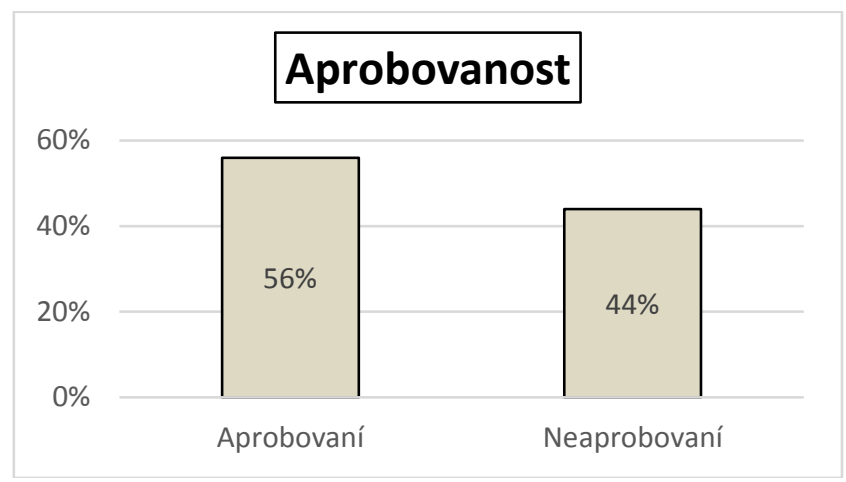

Graf č. 1: Aprobovanost učitele pro výuku Pracovních činností

Učitelé odpovídali na otázku: Jste aprobovaný/á pro výuku předmětu pracovní činnosti s možností odpovědi - ANO/NE. Plnou aprobovanost pro svůj předmět uvedlo $56 \%$ učitelů, což není plně uspokojující. Neaprobovanost učitelů v předmětu PČ je stále aktuální téma. Mnozí neaprobovaní učitelé navíc dostali výuku tohoto předmětu pro doplnění svého úvazku jako okrajový předmět. $Z$ toho pak může vycházet výběr tematických okruhů vzdělávací oblasti Člověk a svět práce, volba pomůcek, kvalifikovanost př́i používání pomůcek, schopnost motivovat žáky k pracovním činnostem - podle orientace a zájmu jednotlivých učitelů. 


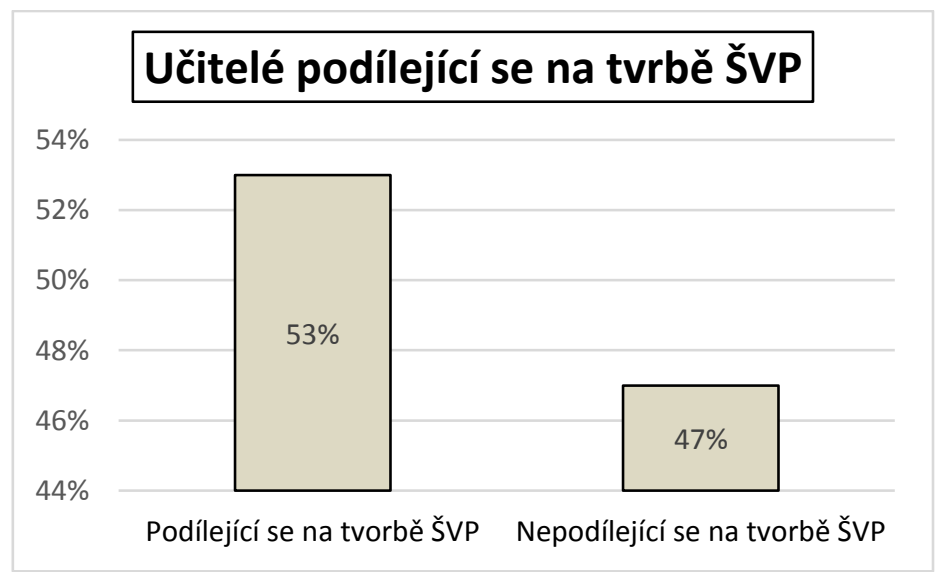

Graf č. 2: Podíl učitelì na tvorbě ŠVP dle kterého realizují současnou výuku PČ

Na přípravě ŠVP se podílelo 53 \% učitelů v blíže neurčeném rozsahu a míree, přesto u těchto učitelů (snad právem) předpokládáme vyšší odbornou profesní kompetenci, orientovanost $\mathrm{v}$ cílech rámcových osnov, větši angažovanost při výuce pracovních činností a hledání inovativních postupů, než u učitelů neaprobovaných, kteří učí předmět tzv. „Z nouze“, plní požadavky výuky podle tematického plánu sestaveného někým jiným, a pravděpodobně postrádají koncepční výhled. Poměrně malá účast učitelů na př́pravě ŠVP, zejména aprobovaných, je rozhodně na závadu a snižuje kvalitu výuky.

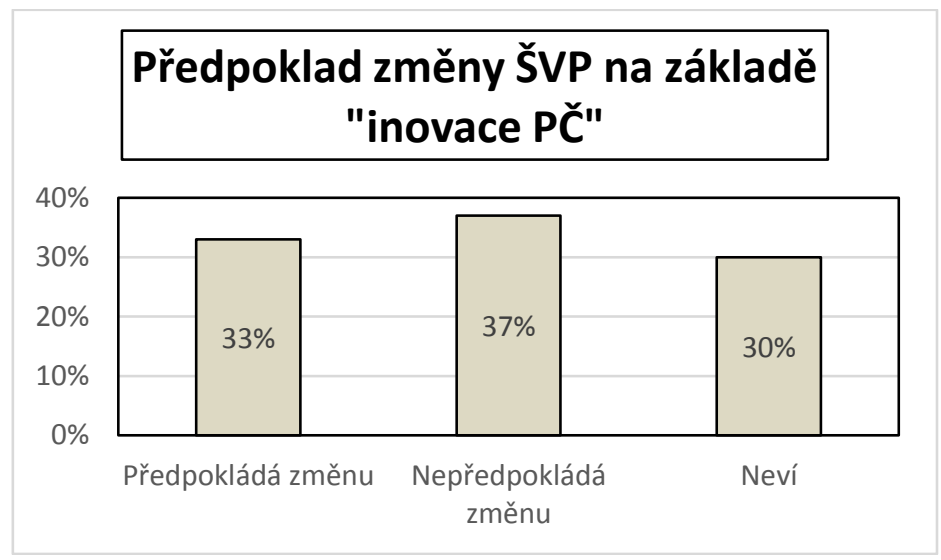

Graf č. 3: Předpokládaná změna stávajicího ŠVP v důsledku "Inovace PČ" 
Očekávání změny bylo rozloženo poměrně rovnoměrně (na otázku „V případě inovace předmětu Pracovní výchova bude třeba změnit naše stávající ŠVP“ - ANO/NE/NEVÍM). Převaha odpovědi NE A NEVÍM naznačuje spíše nechut' ke změně opatření, které se ještě plně nevžilo. Učitelé kromě toho soudí, že možnost výběru navíc zvolených tematických celků (což ŠVP umožňuje), pokrývá oblast výuky pracovních činností dostatečně. Jedná se o práci s technickými prostředky, design a konstruování, pěstitelské práce, provoz a údržba, př́prava pokrmů, práce s laboratorní technikou a využití digitálních technologií. Podle MŠMT (leden 2015) Podle materiálu MŠMT z 21. ledna 2015 změna je očekávatelná: , účinná výchova k volbě povoláni žákủ základnich škol vyžaduje úpravu problematiky Člověk a svět práce $v R V P Z V$ na větši podporu polytechnického vzděláváni a rozvoje podnikavosti na druhém stupni základni školy. “ Ministerstvo také předpokládá, že základní školy při realizaci problematiky Člověk a svět práce v RVP ZV budou spolupracovat a využijí kapacit středních škol.

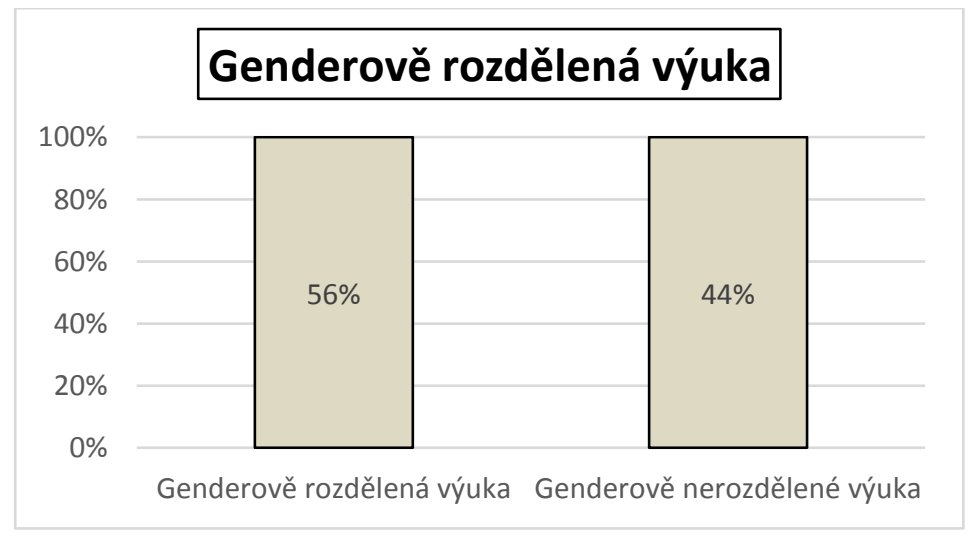

Graf č. 4: Rozdělená výuka na chlapce a dívky

Mírná, ale nepřesvědčivá převaha názoru na prospěšnost dělení výuky na chlapce a dívky pramení pravděpodobně z historického povědomí o tom, že „to tak dříve bývalo“. Může se také projevovat přesvědčení o diferencovanosti pracovních činností podle pohlaví. Otázkou ale zůstává, zda je stále odůvodněné dělit pracovní skupiny žáků na chlapce a dívky, jak tradicionalisticky soudí učitelé. Takováto „separace“ žákủ stále přiživuje onen mýtus, že výuka technických předmětů a oborů na SŠ je vhodná jen pro chlapce a nikoliv i pro dívky, které dávají přednost hlavně vaření a „netechnickým“ oblastem.

Soudě podle dílčích zpráv z programu Investice do vzdělání (ESF) zájem dívek o technické školy v současné době mírně narůstá, přesto je stále nízký. Pravdou ovšem zůstává, že určitá diferencovanost (vybraných) témat je funkční. 


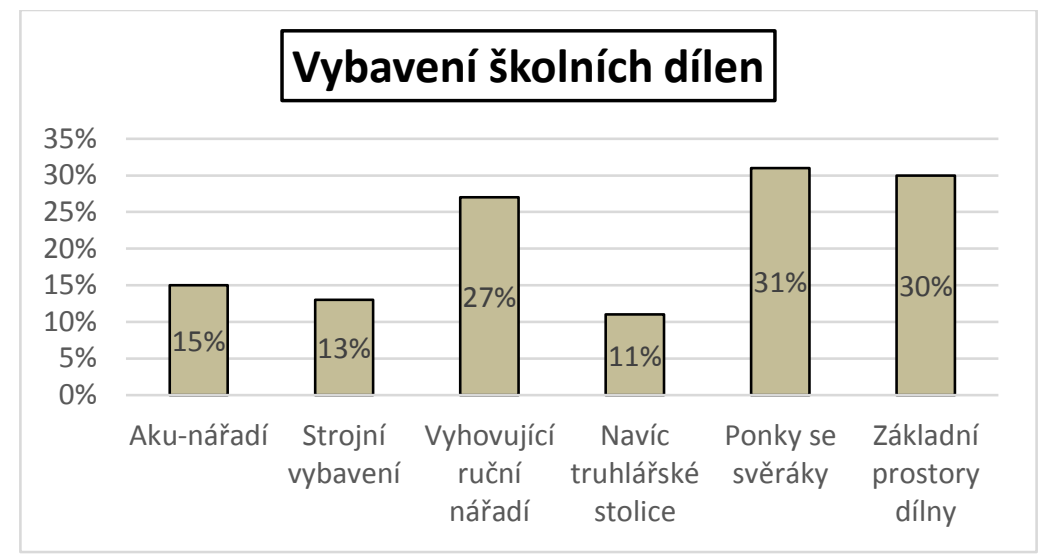

Graf č. 5: Současný stav školních dílen

Při popisu vybavení se jedná pouze o ilustraci toho, jak je vybavená školní dílna - spíše než o názor, jak by měla být vybavena ve vztahu k pracovním činnostem.

Většina škol disponuje samostatnou dílnou. Materiální vybavení školních dílen je však mnohde zastaralé a nevyhovující.

Poznámka: Koncem roku 2015 však školy měly možnost zapojit se do projektu „Rozvoj technických dovedností žáků na druhém stupni základní školy - tzv. „Výzvy č. 57“ MŠMT ČR, financované z fondů EU a státního rozpočtu. Cílem tohoto projektu je rozvoj technického vzdělávání na ZŠ formou vytváření žákovských výrobků. Školy, které se do tohoto projektu zapojily - z celkového počtu základních škol Olomouckém kraji (333) - splnilo podmínky udělení dotace 69 škol, které mohly zakoupit potřebné technické vybavení školních dílen (ruční a elektrické nářadí) včetně pracovních stolů a dalšího dílenského nábytku. Průměrná výše př́spěvku pro jednu školu byla kolem 247000 Kč. Výstupem tohoto projektu byla žákovská portfolia s dokumentací práce na výrobcích, dotazníky a hodnocením učitele. 


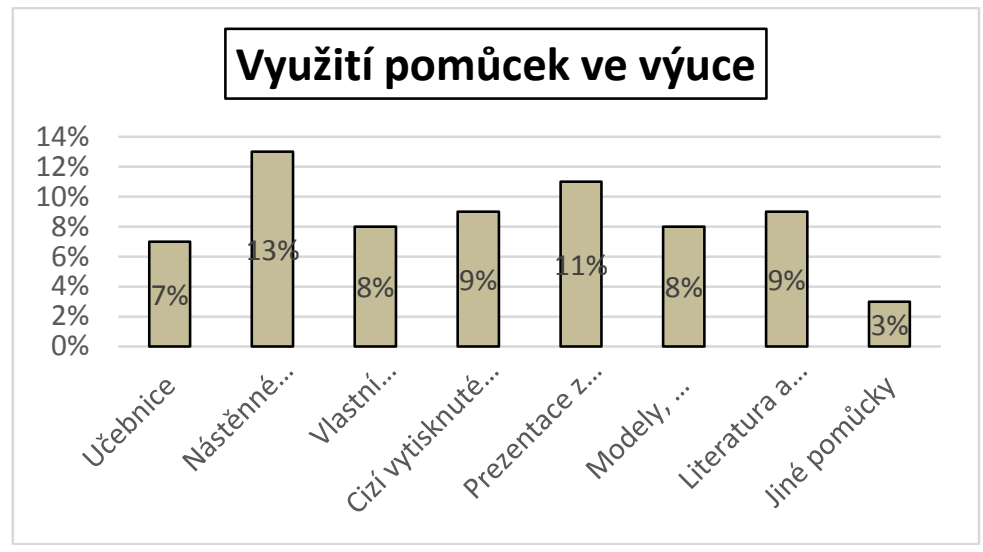

Graf č. 6: Využití učebnich pomi̊cek ve výuce pracovnich činností

Odpovědi odrážejí pojetí výuky, preference a způsoby přípravy a realizace pracovních činností jednotlivých učitelů, nelze z nich vyvozovat jednoznačné závěry.

$\mathrm{Z}$ charakteru pomůcek je zřejmé, že ve výuce se nejedná jen o manuální, praktické činnosti, ale také o teoretické informace, poznatky a pokyny - nástěnné a vytisknuté pomůcky spolu s literaturou a učebnicemi (30\%), počítačové prezentace a modely $19 \%$.

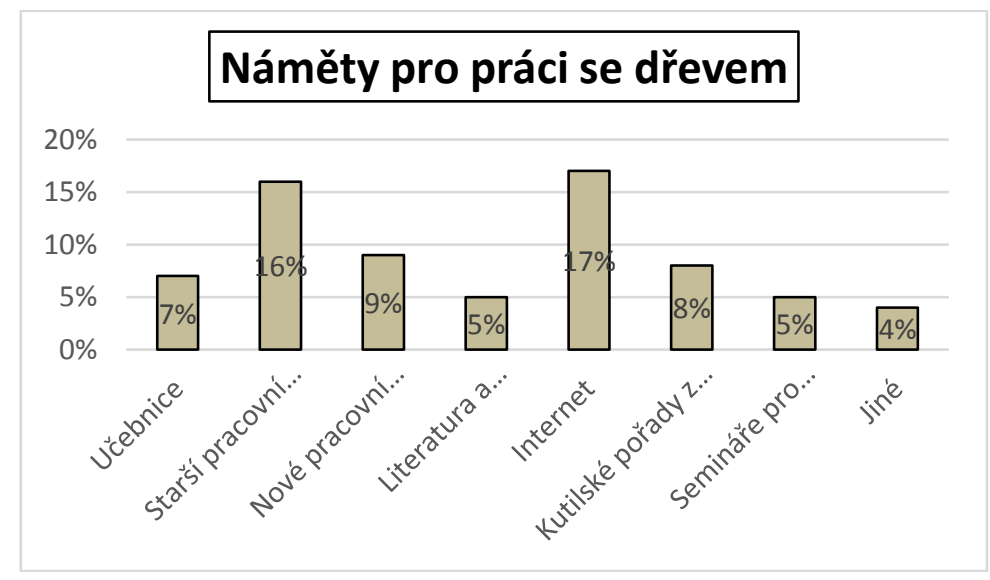

Graf č. 7: Zdroj námětů pro práci se dřevem

V odpovědích na otázku „odkud čerpáte náměty pro práci se dřevem“ (respondenti měli výběr z více možností) se opět odrážejí zájmy a preference jednotlivých vyučujících, stejně 
tak jako stávající vybavení dílen. Malá četnost odpovědí neumožňuje jednoznačné závěry. Uživání starších pracovních listů implikuje závěr o převaze rutiny, četnost internetových námětů o snaze po modernizaci a zrychlení přípravy na výuku. $S$ určitou rezervou se domníváme, že osvědčené pracovní listy plní i dnes svou funkci, i když většina námětů je poněkud zastaralá a užitná hodnota výrobků neodpovídá dnešním představám. Přesto lze s některými náměty úspěšně pracovat a motivovat žáky. Výroba dle těchto pracovních listů je navíc „materiálně dostupná“ a žáci si díky nim mohou vyzkoušet a osvojit základní techniky obrábění.

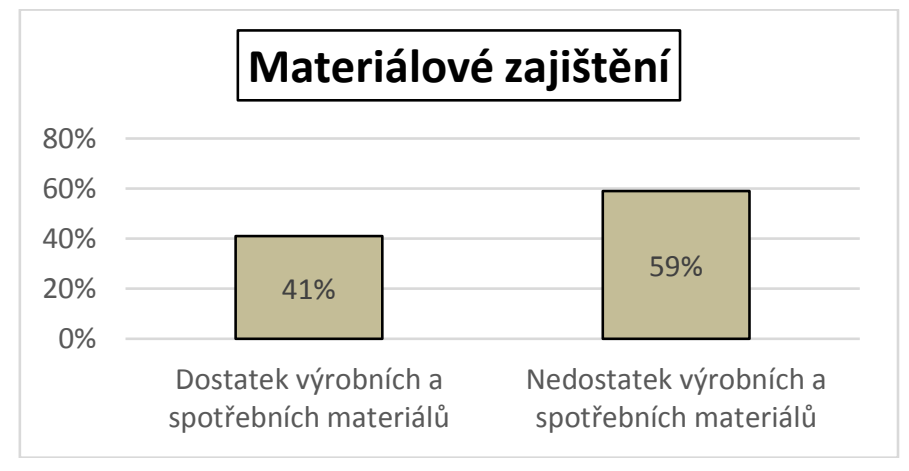

Graf č. 8: Dostatek výrobního a spotřebního materiálu

Učiteli uváděný nedostatek potřebného technického materiálu (konkrétně se jedná o kvalitní plné dřevo a tradiční dřevařské výrobky jako je překližka a sololit) se na mnohých školách řeší zpracováním různých dřevních „odpadů“ nebo dokonce zcela nevhodných materiálů, jako jsou zbytky desek plovoucích podlah, zbytky řeziva z místních dřevařských podniků apod., jak uváděli učitelé v doplňujícím rozhovoru. Obliba a převaha dřeva masivu (jehličnatého) vychází hlavně z dostupnosti a tradice a také umožňuje výrobu prvků lidového charakteru, hraček. 


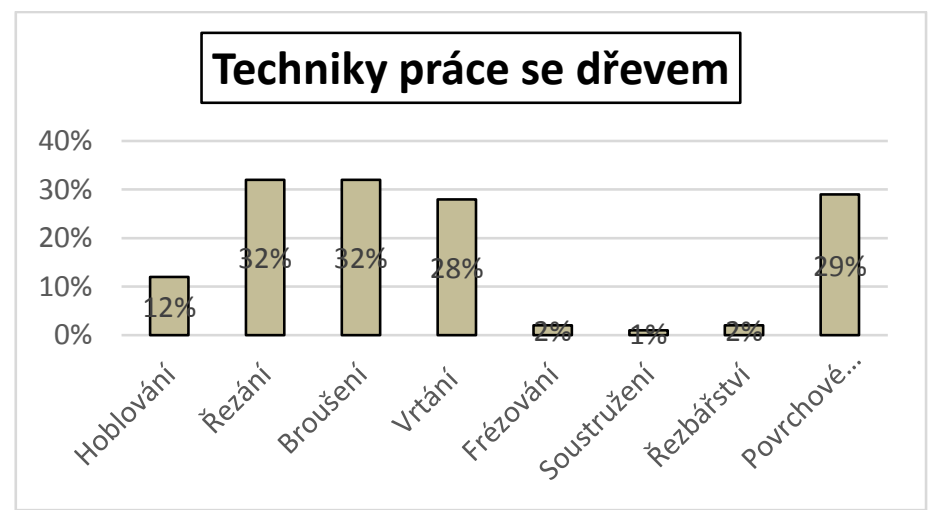

Graf č. 9: Techniky práce se dřevem

Řezání, broušení a vrtání jsou základní pracovní operace, které nevyžadují strojní vybaveními ani vysoké náklady na nářadí a mohou být úspěšně vykonávány žáky a vedeny i neaprobovanými učiteli, pracovní operace nejsou složité. Nižší podíl frézování a soustružení je dán bezesporu náklady na strojní vybavení, nároky na odbornost učitele a vy̌šíími požadavky na bezpečnost práce.

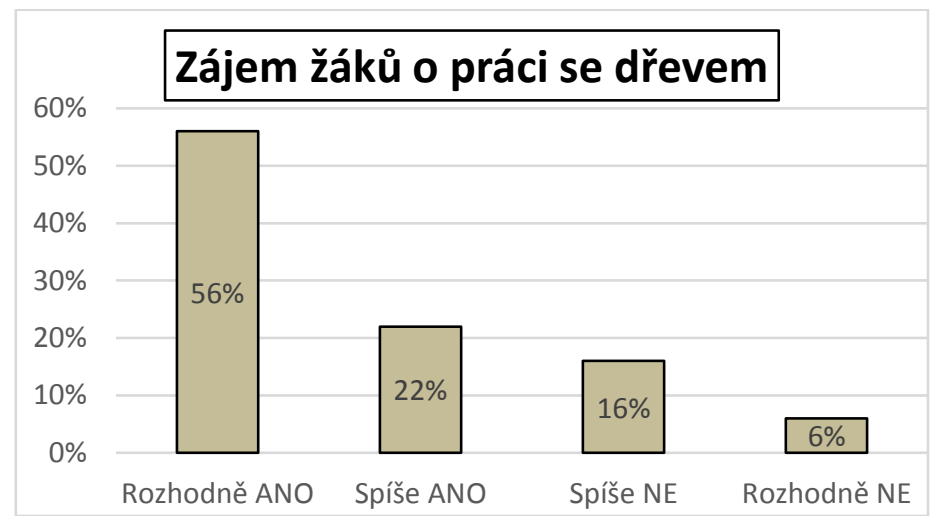

Graf č. 10: Zájem žáki̊ o práci se dřevem

Projevovaný zájem žáků byl hodnocen učiteli, odpovědi svědčí o velké oblibě práce se dřevem, což je sice očekávaný, ale přesto potěšující fakt. Žáky práce se dřevem baví a je pouze na učiteli, respektive škole, zda tento zájem dokáže i v budoucnu dále podporovat a prohlubovat. Zájem žákủ o práci se dřevem je významným motivačním činitelem, podstatný 
je ovšem jeho didaktický smysl. „, V podstatě se jedná o něco jako základni gramatiku práce se dřevem. " (Vigue, J., 2013, s. 115). Dřevo je také spojeno s českou řemeslnou tradicí a nabízí bohatou paletu nápadů a výrobků.

\section{Závěr}

Technická výchova, která je $\mathrm{v}$ současné době realizována prostřednictvím vzdělávací oblasti Člověk a svět práce, prošla během posledních let mnoha změnami. Předmět pracovní vyučování má za cíl rozvíjet technické myšlení a zahrnovat široké spektrum pracovních činností a technologií. Úspěch žáka, celého vyučovacího procesu a dosažení žádoucích kompetencí do značné míry závisí na aprobovanosti učitelů, vybavení školní dílny, dosažitelnosti vhodných materiálů (dřeva a materiálů na bázi dřeva), výběru námětů, přípravě vhodných polotovarů včetně odpovídajících pomůcek a nástrojů. $Z$ dotazníkového šetření vyplynulo, že žáci vedení kvalifikovaným učitelem měli možnost vyzkoušet si široké spektrum obráběcích technik. Výuka pod vedením neaprobovaného učitele se zpravidla omezila pouze na to základní, tj. řezání a broušení.

Pokud by reformní úsilí české školy mělo být úspěšné, je nutno, aby každá škola zvážila, jaké jsou priority školy, co skutečně podporuje vedení školy v dlouhodobém horizontu, zda kvalifikace (aprobovanost) učitelů technické výchovy je dostačující, jaké je materiální zázemí školy, zda jsou finanční prostředky pro udržitelnost výuky i v budoucnu přiměřené, jestli jsou zvoleny vhodné tematické okruhy dle RVP, odpovídají pracovní pomůcky a technické vybavení (ruční nářadí, stroje apod.) současným technickým trendủm.

Úspěšná výuka technických předmětů a realizace cílů ve vzdělávací oblasti Člověk a svět práce vyžaduje řadu podmínek: mít kvalifikovaného učitele zaměřeného na technickou výchovu, mít dobře a bezpečně vybavené prostory (dílny, laboratoře), mít dostatek finančních prostředků na pravidelnou údržbu a obnovu nářadí a zařízení a na nákup spotřebního materiálu, věnovat výuce dostatek času v učebním plánu, protože získat pracovní dovednosti a návyky vyžaduje prostor pro cvik, a cvik chce čas. Bez splnění všech těchto podmínek je výuka technických předmětů více či méně formální, pro žáky demotivující, pro učitele vysilující a ve výsledku nedosahuje očekávaných výstupů.

Závěrem tedy můžeme uvést, že důležitost výuky o zpracování dřeva na základní škole hraje pro uchazeče důležitou roli při rozhodování a výběru vhodného učebního popř̀. studijního oboru na střední technické škole. Rozhodování žáků - absolventů základní školy neprobíhá jen na základě teoretické informovanosti, ale hlavně na základě osobních (a motivačních) zkušeností z praktické - reálné výuky ve školní dílně. Tak zároveň přirozeným způsobem dochází $\mathrm{k}$ naplňování okřídleného výroku „praxe bez teorie je slepá a hluchá, ale teorie bez praxe je dutá a prázdná ... a neni nic praktičtějšího než dobrá teorie " (Hüttner, A. 2015). Také nás to opravňuje k přesvědčení, že úspěšně realizovaná výuka technické výchovy na ZŠ přispěje k větší poptávce po technických oborech na středních školách. 


\section{Literatura}

Cimra, M. \& Očkajová, A. (2015). Testování psychomotorických zručností Žižkov jako súčast' pedagogického experimentu. Technika a vzdělavanie, 4, č.1, s.18-22. FPV UMB Banská Bystrica.

Hüttner, A. (2015). Theorie-Praxis-Verknüpfungen. Integrative Inhaltsbestandteile der technischen Allgemeinbildung. Zeischrift für Technik im Unterricht. 40. Jahrgang, 3. Quartal 2015, s. 31-38.

Chráska, M. \& Kočvarová, I. (2015). Kvantitativni metody sběru dat v pedagogických výzkumech. Zlín, Univerzita Tomáše Bati ve Zlíně, fakulta humanitních studií.

Knecht, P. \& Šumavská, G. (eds.). (2011). Moderní odborná škola: názory učitelů pilotnich škol na kurikulární reformu. Praha: NúV.

Kropáć, J. (2004). Didaktika technických predmětů: vybrané kapitoly. Olomouc: Univerzita Palackého v Olomouci.

MŠMT dostupné na: http://clanky.rvp.cz.clanek/c/ZVI/19607/metodicke doporuceni-kvyuce-vzdelavaciho oboru-clovek- a -svet- práce- na 2-stupni-zakladnich skol.html

Moree, D. (2013). Učitelé na vlnách transformace. Kultura školy před rokem 1989 a po něm. Praha, UK.

Upravený Rámcový vzdělávací program pro základni vzdělávání platný od 1. 9. 2013 [online]. [cit. 2016-01-10]. Dostupné z: msmt.cz/vzdelavani/zakladnivzdelavani/ upravenyramcovy-vzdelavaci program pro základní vzdělávání.

Vigué, J. (2013). Dřevo od A do Z. Čestlice: Rebo pro Klub čtenářù.

Vzdèlávací program Základní škola: včetně osnov Ekologického přirodopisu, osnov volitelných předmètů, úprav a doplňkư, učebních plánů s rozšǐreným vyučováním. (2001). MŠMT ČR, Praha: Fortuna.

MŠMT ČR. (2001). Rámcový vzdělávací program pro základní vzdèlávání. Dostupné z: http://www.msmt.cz/vzdelavani/zakladnivzdelavani/ upraveny-ramcovy-vzdelavaciprogram-pro-zakladni-vzdelavani 